\title{
GIRO CULTURAL USP
}

\author{
USP CULTURAL TOUR
}

O Giro Cultural USP é um novo Programa da Pró-Reitoria de Cultura e Extensão Universitária da Universidade de São Paulo. Ele objetiva estimular a divulgação da grande riqueza do patrimônio arquitetônico, artístico e cultural - material e imaterial - da USP, muitas vezes, desconhecida pela própria comunidade uspiana e pelo público em geral que frequenta ou visita a Universidade.

Para divulgar os diferentes equipamentos científicos e culturais existentes na Universidade de São Paulo, serão realizadas visitas, monitoradas por alunos estagiários, com conteúdo preparado e orientado por docentes desta Universidade.

Os roteiros inicialmente propostos são:

- $\quad$ I $^{\mathrm{O}}$ Roteiro: Visita ao campus da Cidade Universitária (Cidade Universitária Armando de Salles Oliveira - CUASO), no Butantã.

- $\quad 2^{\circ}$ Roteiro: Cultural, com paradas no Museu de Arte Contemporânea (MAC-USP), Paço das Artes, Museu do Brinquedo (Faculdade de Educação - FE) e Instituto de Estudos Brasileiros (IEB).

- $\quad 3^{\circ}$ Roteiro: Científico, com paradas no Museu do Instituto de Geociências (IGc), Museu do Instituto Oceanográfico (IO), Show de Física (Instituto de Física - IF), Museu de Anatomia Veterinária (Faculdade de Medicina Veterinária e Zootecnia - FMVZ).

Em parceria com a Prefeitura da USP Capital, contaremos com ônibus e motorista para a realização dos Roteiros. Cada um deles possui a duração aproximada de duas horas. As partidas e retornos serão no Centro de Visitantes, localizado em proximidade à Portaria I da Universidade.

As inscrições podem ser realizadas mediante escolha individual ou constituindo turmas de, no máximo, 35 pessoas. Basta enviar os dados pessoais (nome completo e telefone para contato), informar sua relação com a Universidade (docente, discente, funcionário ou público externo), especificando o dia, o horário e o roteiro escolhido, para o e-mail girocultural@usp.br.

Os roteiros são gratuitos. Escolham o melhor dia e horário: vocês são nossos convidados! 